\title{
Glucose utilization and the PI3-K pathway: mechanisms for cell survival in preimplantation embryos
}

\author{
Joan K Riley ${ }^{1}$ and Kelle H Moley ${ }^{1,2}$ \\ ${ }^{1}$ Department of Obstetrics and Gynecology and the ${ }^{2}$ Department of Cell Biology and Physiology, Washington \\ University School of Medicine, 4911 Barnes-Jewish Hospital Plaza, St Louis, Missouri 63110, USA
}

Correspondence should be addressed to KH Moley; Email: moleyk@wustl.edu

\begin{abstract}
The maintenance of optimal glucose utilization during the preimplantation period is critical for embryo survival. A decrease in glucose transport during preimplantation development has been linked to the early steps of programmed cell death in these embryos. Decreased glucose transport is not thought to be simply a consequence of cell death, rather it is thought to be a trigger that can initiate the apoptotic cascade. Extensive apoptosis during the preimplantation period may manifest later in pregnancy as a malformation - or miscarriage, if cell loss is excessive. Phosphatidylinositol 3-kinase (PI3-K) is a known regulator of a number of physiologic responses including cellular proliferation, growth, and survival as well as glucose metabolism. Studies performed in other cell systems have demonstrated that the PI3-K pathway plays a critical role in maintaining glucose transport and metabolism. This review will present the current evidence that suggests that PI3-K is vital for preimplantation embryo survival and development. In addition, data demonstrating that PI3-K activity is important for glucose metabolism during this early developmental period will be discussed.

Reproduction (2006) 131 823-835
\end{abstract}

\section{Introduction}

Glucose uptake and utilization is vital for embryo survival and development during the preimplantation period. A decrease in glucose uptake during this stage can compromise the developing embryo. The preimplantation period extends from the time of fertilization through the 1-cell, 2-cell and 4-cell stages to the morula and finally to the blastocyst stage. Prior to the blastocyst stage of preimplantation development, murine embryos are unable to metabolize glucose via glycolysis. During the early blastocyst stage, the embryo differentiates from totipotent cells into two cell lineages: the trophectoderm (TE) that develops into the placenta and the inner cell mass (ICM) which gives rise to the embryo proper. It is during this time that embryonic metabolism switches from the oxidation of lactate and pyruvate via the Krebs cycle and oxidative phosphorylation to the anaerobic metabolism of glucose through glycolysis (Leese \& Barton 1984, Wales 1986). This change in substrates is thought to be due to the biosynthetic and developmental demands placed on the embryo as the blastocyst creates the fluid-filled blastocoel and prepares for implantation.

In eucaryotes, glucose enters a cell by one of two mechanisms. Glucose transport may be an active process in which glucose uptake occurs via sodium coupled glucose transporters (SGLT). The presence of SGLTs during preimplantation embryo development is equivocal and this review will focus on the family of facilitative glucose transporters known as GLUTs. Glucose transport across cell membranes via GLUT proteins is an energy independent process in which glucose is transported down its concentration gradient. Currently, there are thirteen members of the facilitative glucose transporter family, GLUT1-12 and the $\mathrm{H}^{+}$coupled myo-inositol-transporter (HMIT) (Joost et al. 2002, Wood \& Trayhurn 2003). The GLUT family of proteins has been subdivided into three classes: class I consists of GLUT1-4; class II contains GLUT5,7,9,11; and class III consists of GLUT6,8,10,12 and HMIT (see Joost \& Thorens 2001, Joost et al. 2002). GLUTs exhibit a high degree of sequence homology, however they differ in their substrate specificity, kinetic characteristics, tissue and subcellular distribution as well as their response to extracellular stimuli. Members of the GLUT family contain an intracellular amino- and carboxy-terminus, 12 membrane spanning domains, a glycosylated extracellular loop and an intracellular loop (Mueckler et al. 1985, Cope et al. 1994).

\section{Facilitative glucose transporters in preimplantation development}

Glucose transport in murine preimplantation embryos has previously been attributed to the known facilitative 
glucose transporters, GLUT1, GLUT2, and GLUT3 (Hogan et al. 1991, Aghayan et al. 1992, Pantaleon et al. 1997, Moley et al. 1998b) however more recently the expression of a growing number of GLUTs has been detected in preimplantation embryos. The function of these newly identified transporters during the preimplantation period is largely unknown. One of the first transporters to be characterized in preimplantation embryos was GLUT1. GLUT1 mRNA is expressed throughout preimplantation development, namely from the 1-cell through the blastocyst stage in the mouse (Hogan et al. 1991, Aghayan et al. 1992, Morita et al. 1992), rabbit (Robinson et al. 1990), cow (Lequarre et al. 1997, Wrenzycki et al. 1998, Navarrete Santos et al. 2000, Augustin et al. 2001) and human (Dan-Goor et al. 1997). Interestingly, GLUT1 was shown by immunofluorescent confocal microscopy to be expressed in the pronuclei of oocytes and in the nucleus of cleavage stage embryos (Pantaleon et al. 2001). This study suggests an additional yet undefined role for GLUT1 which the authors propose may be related to the physiological state of the cell. While GLUT1 is expressed throughout preimplantation development it is predominantly cytoplasmic until compaction (Pantaleon et al. 2001). In rabbit blastocysts GLUT1 is expressed predominantly at the basolateral surface of the polarized TE cells (Robinson et al. 1990). In contrast, the cellular distribution of GLUT1 was found to be different in murine blastocysts where it was expressed on the apical and basolateral surfaces of the TE cells as well as in intercellular membranes (Aghayan et al. 1992). In addition, it was expressed on the membranes of the ICM. A separate study revealed a more restricted expression pattern for GLUT1 in murine blastocysts namely on the basolateral surface of TE cells and on the plasma membrane of the ICM (Pantaleon et al. 1997). It is hypothesized that the function of GLUT1 in the developing embryo given its cell surface expression in the ICM is to transport glucose into these cells from the embryonic extracellular space (Pantaleon et al. 1997).

GLUT2 expression in preimplantation embryos is controversial. GLUT2 transcripts were detected at the 8-cell/compacted morula stage (Hogan et al. 1991, Schultz et al. 1992) and the protein was detected at the blastocyst stage in mouse embryos (Aghayan et al. 1992, Schultz et al. 1992). In addition bovine embryos were shown to express GLUT2 transcripts during blastocyst elongation at d14 and d16 (Augustin et al. 2001). GLUT2 is reportedly expressed on the basal membrane of TE cells, intracellular vesicles, and on the plasma membrane of the ICM (Aghayan et al. 1992). The function of GLUT2 at these locations in the blastocysts is not yet defined. However it has been speculated that GLUT2 may be responsible for glucose transport into the blastocoel cavity (Pantaleon et al. 1997). Other studies also conducted in mice did not demonstrate GLUT2 expression (Morita et al. 1992, Tonack et al. 2004). In addition, studies conducted in other species namely rabbit and cow did not find
GLUT2 to be expressed during the preimplantation period (Augustin et al. 2001, Navarrete Santos et al. 2004a).

GLUT3 transcripts are detected from the 4-cell through the blastocysts stage of murine development (Pantaleon et al. 1997). GLUT3 mRNA has also been detected from the 2/4-cell stage through the blastocyst stage in bovine embryos (Augustin et al. 2001). In mice, GLUT3 protein is detected starting at the late 4-cell stage, where the immunoreactivity is weak and the protein is present in cytoplasmic vesicles (Pantaleon et al. 1997). It remains in vesicles through the 6- and 8-cell stages. In the uncompacted morula this protein is present at the plasma membrane. As the embryo develops from the compacted morula to the blastocyst stage, GLUT3 expression is detected on the apical surface of the polarized TE cells. It is thought that the function of GLUT3 in blastocysts is to facilitate the uptake of maternal glucose. In addition, down-regulation of GLUT3 using an antisense oligonucleotide in pooled blastocysts demonstrated a lower percentage of embryos progressing to a blastocyst stage, suggesting that this protein may facilitate blastocyst formation by its ability to transport glucose. Since this treatment did not fully knock down GLUT3 protein expression, it is difficult to conclude that GLUT3 is essential for preimplantation embryo development.

The facilitative fructose transporter, GLUT5, is expressed in but not limited to tissues which are insulin sensitive in both humans and rodents (Shepherd et al. 1992, Kristiansen et al. 1997, Darakhshan et al. 1998, Hajduch et al. 1998) where it transports dietary fructose into cells. Fructose is present in human uterine fluid and thus at the blastocysts stage of development, the early embryo is exposed to this hexose sugar (Casslen \& Nilsson 1984). GLUT5 transcripts were not detected in rabbit blastocysts (Navarrete Santos et al. 2004a). However, GLUT5 transcripts can be detected at the 8/16-cell stage in bovine embryos the point at which embryonic genome activation occurs (Augustin et al. 2001). The authors suggest that fructose uptake through GLUT5 in preimplantation embryos may correspond with the shift from the pentose-phosphate pathway towards the production of ribose-5-phosphate which is necessary for nucleotide synthesis.

Most recently, two additional facilitative glucose transporters have been identified in the preimplantation embryo, GLUT9 and GLUT12. Three different isoforms of GLUT9 have been identified in the mouse embryo (Carayannopoulos et al. 2004). The full-length isoform (GLUT9a) contains 12 transmembrane-spanning domains. The two additional isoforms, GLUT9a $\mathrm{a}_{(\Delta 209-316)}$ and GLUT9b $_{(\mathrm{NH} 2 \mathrm{~b} \Delta 209-316) \text {, }}$ are short forms of GLUT9 that contain 10 transmembrane-spanning domains. These isoforms have deleted transmembrane domains 6 and 7 and appear to be splice variants of the same gene. GLUT9b $_{\left(\mathrm{NH}_{2} \mathrm{~b} \Delta 209-316\right)}$ contains an alternate aminoterminus but the remainder of the protein is identical to GLUT9a $a_{(\Delta 209-316)}$. The short isoforms of GLUT9 have not yet been identified in humans. Two of the GLUT9 
isoforms, GLUT9a and GLUT9a $a_{(\Delta 209-316) \text {, have been }}$ shown to transport glucose. However, of these two only

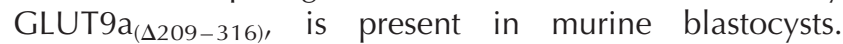
GLUT9a $(\Delta 209-316)$, is expressed at the plasma membrane in 1-cell and 2-cell zygotes and in an intracellular compartment in TE cells at a blastocyst stage. The downregulation of GLUT9a $a_{(\Delta 209-316)}$ expression using antisense oligonucleotides did not result in decreased glucose uptake in blastocysts nor in the induction of apoptosis. However, when antisense treated embryos were transferred into pseudo-pregnant female mice an increase in pregnancy

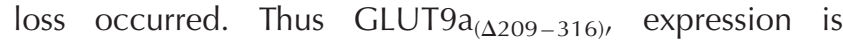
important during early preimplantation development.

GLUT12 is potentially another insulin-sensitive glucose transporter (Rogers et al. 2002). The presence of GLUT12 transcripts was examined at the 2-cell, morula and blastocyst stages of development in murine embryos. GLUT12 expression was strongest at the 2-cell stage and declined thereafter such that the presence of GLUT12 transcripts at the morula and blastocyst stage was very low. Preliminary experiments using an antiserum raised against human GLUT12 (Rogers et al. 2002) showed immunoreactivity in 2-cell embryos but not in blastocysts. The promoter region of murine GLUT12 contains sequences that are homologous to known insulin response elements (Zhou et al. 2004). However, whether GLUT12 is an insulin responsive glucose transporter expressed at a protein level in murine embryos remains to be determined.

In murine blastocysts, insulin and IGF-I stimulate glucose uptake through the IGF-I receptor (Gardner \& Leese 1988, Harvey \& Kaye 1991, Pantaleon \& Kaye 1996, Carayannopoulos et al. 2000). Two insulin responsive GLUTs have been identified in preimplantation embryos, namely GLUT8 and GLUT4. In a non-insulin-stimulated state GLUT8 is predominantly located in the cytoplasm of both the ICM and TE in murine blastocysts (Carayannopoulos et al. 2000). Upon insulin stimulation the protein translocates to the plasma membrane of the TE cells. The inhibition of GLUT8 expression via antisense oligonucleotides results in the abrogation of insulin-stimulated glucose uptake at the blastocyst stage. Thus GLUT8 plays a role in insulin-stimulated glucose uptake in murine blastocysts. GLUT8 expression has also been documented in both rabbit and bovine embryos. GLUT8 was only expressed at the blastocyst stage in rabbit embryos (Navarrete Santos et al. 2004a) whereas it was expressed from the 2-cell through the blastocyst stage in bovine embryos (Augustin et al. 2001). The presence of GLUT4 in mammalian preimplantation embryos is controversial. GLUT4 was not detected in either human or murine preimplantation embryos (Hogan et al. 1991, Aghayan et al. 1992, Schultz et al. 1992, Dan-Goor et al. 1997). In contrast, GLUT4 expression has been reported in other species namely bovine, rabbit, rat and C57/BL6 murine blastocysts (Navarrete Santos et al. 2000, 2004a, Augustin et al. 2001, Korgun et al. 2001, Tonack et al. 2004). In murine embryos, GLUT4 is expressed in the cytoplasm of both the ICM and TE where it maintains a perinuclear staining pattern (Tonack et al. 2004). Similar to murine blastocysts, rabbit blastocysts displayed cytoplasmic and perinuclear GLUT4 staining. In addition, GLUT4 expression was detected at the plasma membrane of TE cells and in association with nuclear membranes in the rabbit embryos (Navarrete Santos et al. 2004a). To date however, GLUT4 has not been shown to translocate to the plasma membrane in response to either insulin or IGF-1. Thus it remains to be seen whether GLUT4 is involved in insulin-stimulated glucose uptake in preimplantation embryos.

\section{Presence and function of PI3-K/Akt in mammalian preimplantation embryos}

Mammalian preimplantation embryos express a number of growth factors and growth factor receptors that are critical during embryo development (for review see Hardy \& Spanos 2002). Growth factors have been shown to affect preimplantation embryo gene expression, metabolism and cell death and thus they may have profound effects on embryo development. Insulin and IGF-I are important regulators of cell growth and differentiation and have been shown to have both mitogenic and anti-apoptotic effects on mammalian preimplantation embryos. Studies have demonstrated that the addition of physiologic levels of insulin or IGF-I during in vitro culture results in decreased apoptosis (Herrler et al. 1998, Spanos et al. 2000, Byrne et al. 2002, Makarevich \& Markkula 2002, Augustin et al. 2003, Sirisathien \& Brackett 2003, Fabian et al. 2004) and or increased cellular proliferation in human, mouse, rabbit and bovine blastocysts (Matsui et al. 1995, Herrler et al. 1998, Byrne et al. 2002, Makarevich \& Markkula 2002, Augustin et al. 2003). Insulin treatment of cultured murine and bovine embryos results in increased cell number specifically in the ICM of the developing blastocyst (Harvey \& Kaye 1990, Gardner \& Kaye 1991, Smith et al. 1993, Sirisathien et al. 2003). Thus insulin and insulin-like growth factors support embryo growth and survival.

Given the anti-apoptotic nature of insulin and IGF-I, inhibition of the IGF-I receptor should lead to increased apoptosis during development. Indeed studies have demonstrated that down-regulation of the IGF-I receptor via exposure to high IGF-I and insulin concentrations results in the induction of apoptosis in murine blastocysts (Chi et al. 2000b). The transfer of the high IGF-I treated blastocysts into pseudo-pregnant female recipient mice revealed increased pregnancy loss (Pinto et al. 2002b). Thus the activation of growth factor receptors, such as insulin and IGF-I, during the preimplantation period in mammals is vital for embryo survival and development. The signal transduction mechanisms by which growth factors mediate their effects in preimplantation embryos are beginning to be elucidated.

A number of growth factor receptors activate phosphatidylinositol 3-kinase (PI3-K). Growth factor activation of 
the PI3-K pathway has been reviewed elsewhere (Brazil \& Hemmings 2001, Cantley 2002, Thompson \& Thompson 2004, Woodgett 2005). PI3-Ks are a family of enzymes that phosphorylate phosphoinositides (Chan et al. 1999). These kinases are divided into three classes, growth factors such as insulin and IGF-I activate class I PI3-Ks. Once activated by cell surface receptors class I PI3-Ks phosphorylate plasma membrane phosphoinositides thus generating docking sites for pleckstrin homology domain containing proteins such as the serine-threonine kinase Akt. It is generally believed that Akt is the primary mediator of the anti-apoptotic signal generated via the PI3-K pathway (Dudek et al. 1997, Khwaja et al. 1997, Philpott et al. 1997, Songyang et al. 1997). PI3-K activity is known to regulate a number of physiologic responses including cellular proliferation, growth, and survival as well as glucose metabolism. Recently, studies have described the expression of PI3-K and its downstream target the serinethreonine kinase Akt in preimplantation embryos.

$\mathrm{PI} 3-\mathrm{K}$ is a heterodimeric enzyme that consists of a p85 regulatory subunit and a p110 catalytic subunit. Murine 2-cell embryos were shown to express the mRNA of multiple PI3-K isoforms including $\mathrm{p} 85 \alpha$ and $\beta$ and $\mathrm{p} 110 \alpha, \beta$, $\gamma, \delta$ (Lu et al. 2004). In addition, Kawamura et al. (2005) demonstrated the presence of p110 transcripts from the oocyte through the hatched blastocysts stage of murine preimplantation development. PI3-K activity results in the recruitment of Akt to the plasma membrane. Navarrete Santos et al. (2004b) demonstrated the presence of Akt protein in rabbit blastocysts. The Akt protein present in the rabbit blastocysts was phosphorylated indicating that at this stage of development, Akt is likely to be activated by growth factors present in its milieu. A final study examined the expression of both PI3-K and Akt protein throughout murine preimplantation development (Fig. 1). Using pan p85, p110 and Akt antibodies it was determined that both PI3-K subunits and Akt are expressed from the 1-cell through the blastocyst stage of murine preimplantation development (Riley et al. 2005b). These proteins are localized predominantly at the cell surface from the 1-cell through the morula stage. At the blastocyst stage, both PI3-K and Akt exhibited an apical staining pattern in the TE cells. Similar to what Navarrete Santos et al. (2004b) reported in rabbit, Akt was phosphorylated throughout murine preimplantation embryo development and its presence at the plasma membrane is a reflection of its activation status. Most recently, the presence of the PI3-K pathway has also been detected in human blastocysts using a cDNA microarray approach (Adjaye et al. 2005). These studies establish the presence of the PI3-K/Akt pathway in preimplantation embryos and the phosphorylation status of Akt suggests the pathway is active during this developmental period.

Targeted gene deletion experiments initially revealed the importance of the PI3-K pathway during embryo development. The physiological roles of different classes and isoforms of $\mathrm{PI} 3-\mathrm{K}$ are complex and are beginning to become more well defined. Deletion of certain PI3-K subunits leads to embryonic lethality. Mice deficient in the p110 $\alpha$ catalytic subunit of PI3-K die in utero between E9.5 and E10.5 (Bi et al. 1999). The null mice have a proliferation defect (Bi et al. 1999) and multiple vascular defects (Lelievre et al. 2005). Deletion of the p110 $\beta$ subunit leads to early embryonic lethality suggesting a more critical role for this protein during development (Bi et al. 2002). A few p110 $\beta$ deficient embryos were detected at E3.5 (blastocyst stage) however there is a deficit in the number of homozygous knockout embryos detected during this period of development according to Mendelian ratios. Thus both $\mathrm{p} 110 \alpha$ and p110 $\beta$ are vital during embryonic development. The deletion of some PI3-K isoforms does not result in embryonic lethality implying either that these isoforms are not important during development or that functional redundancy exists among these proteins.

The physiologic importance of the PI3-K pathway has recently been documented during the preimplantation period. Lu et al. (2004) demonstrated the importance of the $\mathrm{PI} 3-\mathrm{K}$ pathway in mammalian preimplantation embryo development by showing that the activation of PI3-K by an embryonic trophic factor, platelet-activating factor (PAF), is critical for embryo development and survival. PAF treatment of 2-cell embryos results in a transient increase in calcium that is inhibited by both LY-294002 and wortmannin implying that PI3-K activity is required for this PAF-induced biological response. In addition, a separate global gene expression study demonstrated that genes involved in inositol phosphate and calcium signaling such as Pik3c2a (a class II PI3-K $\alpha$ polypeptide) are increased in activated as compared with dormant blastocysts (Hamatani et al. 2004). The importance of the PI3-K pathway during the preimplantation period was highlighted by a study that demonstrated that inhibition of PI3-K results in decreased numbers of embryos that develop to the morula and blastocyst stage in vitro when cultured from a zygote stage, similar to Pafr deficient embryos (Lu et al. 2004). The blastocysts that did develop contained fewer cells and a larger number of fragmented nuclei. The effects induced by the PI3-K inhibitors were dose-dependent. Interestingly, if the embryos were only exposed to the PI3-K inhibitors from the zygote through the 2-cell stage and then cultured to the blastocyst stage there was again a decrease in cell number and an increase in the number of fragmented nuclei. However, the effect of this limited treatment was not as great as when the embryos were cultured with the inhibitors throughout preimplantation development. Thus activation of the PI3-K pathway, in this case via PAF, is critical for the survival and development of the preimplantation embryo.

Insulin has been shown in other cell systems to activate the PI3-K pathway and thus stimulate glucose uptake by causing the translocation of insulin responsive GLUTs, such as GLUT4, to the plasma membrane (for review see Welsh et al. 2005). It is controversial whether insulin-stimulation results in the activation of this pathway 


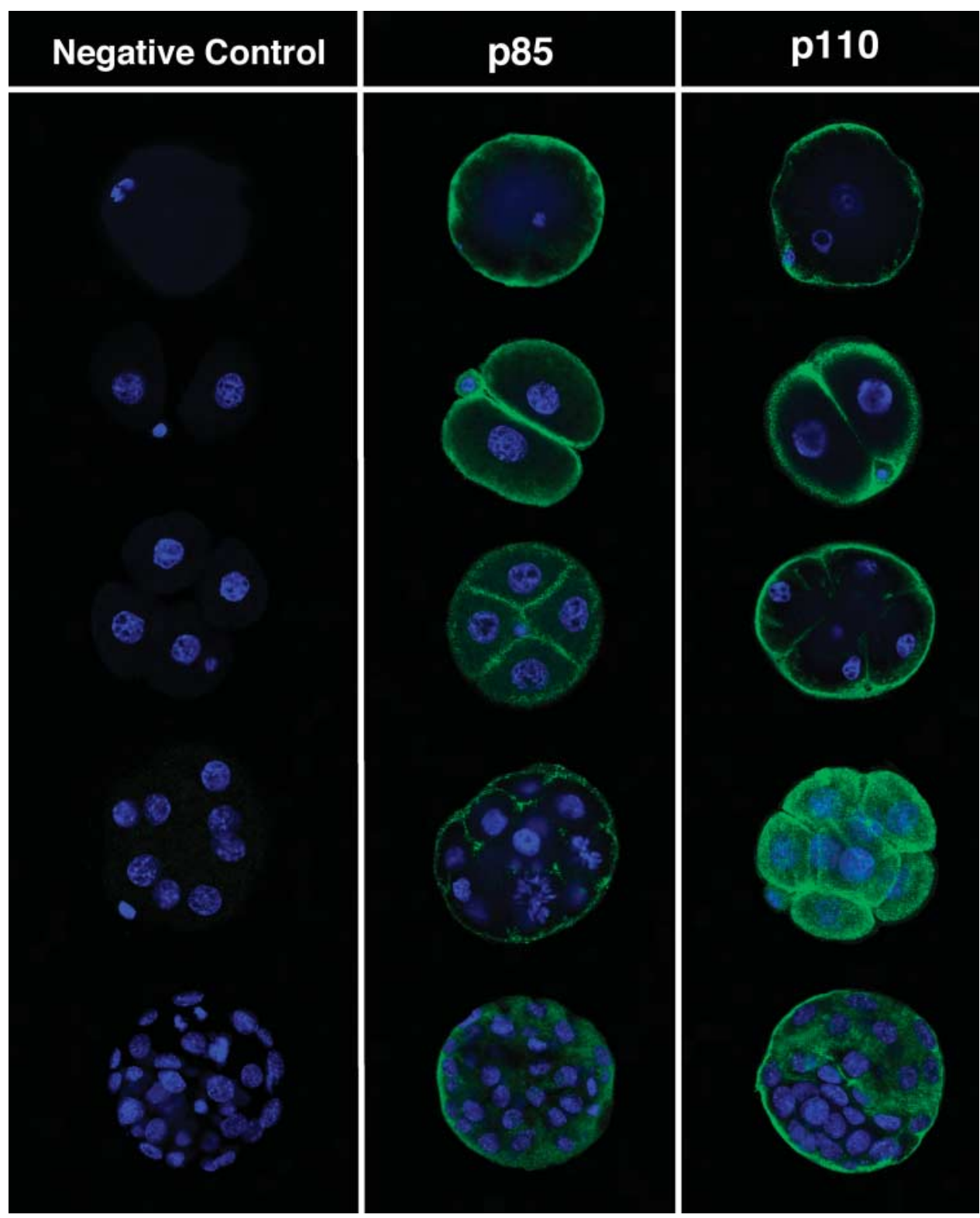

Figure 1 Detection of PI3-K subunits, p85 and p110, in preimplantation embryos. Reproduced from Riley et al. 2005b. Preimplantation mouse embryos were retrieved at different stages of development and stained with either preimmune antisera as a negative control or with antibodies specific for the p85 or p110 subunit of PI3-K. The embryos were then incubated with a secondary antibody, Alexa Fluor 488 goat anti-rabbit or donkey anti-goat IgG (green fluorescence). Embryos were counterstained with TO-PRO-3 iodide, which stains nuclei (blue channel).

in preimplantation embryos. Navarrete Santos et al. $(2004 b)$ found that insulin-stimulation results in the activation of the mitogen-activated protein kinase (MAPK) pathway but not the PI3-K/Akt pathway in rabbit blastocysts. In contrast, Riley et al. (2005b) demonstrated insulin treatment of murine blastocysts resulted in a 2 -fold increase in Akt phosphorylation in comparision with controls. Moreover, LY-294002 and wortmannin were shown to completely inhibit insulin-stimulated glucose uptake at the blastocyst stage (Fig. 2). Thus whether insulin triggers the activation of the PI3-K/Akt pathway and thereby regulates glucose homeostasis in mammalian blastocysts remains to be determined.

Other experiments highlighting the functional importance of the $\mathrm{PI} 3-\mathrm{K}$ pathway during the preimplantation period include those demonstrating that inhibition of the $\mathrm{PI} 3-\mathrm{K}$ pathway results in decreased blastocyst hatching (Riley et al. 2005b). Blastocyst hatching from the zona pellucida is required for successful implantation. Although hatching is delayed in these embryos it does occur as blastocysts that are cultured in vitro for $24 \mathrm{~h}$ in the presence of LY-294002 and then transferred back into pseudo-pregnant female recipient mice, resulted in approximately the same 


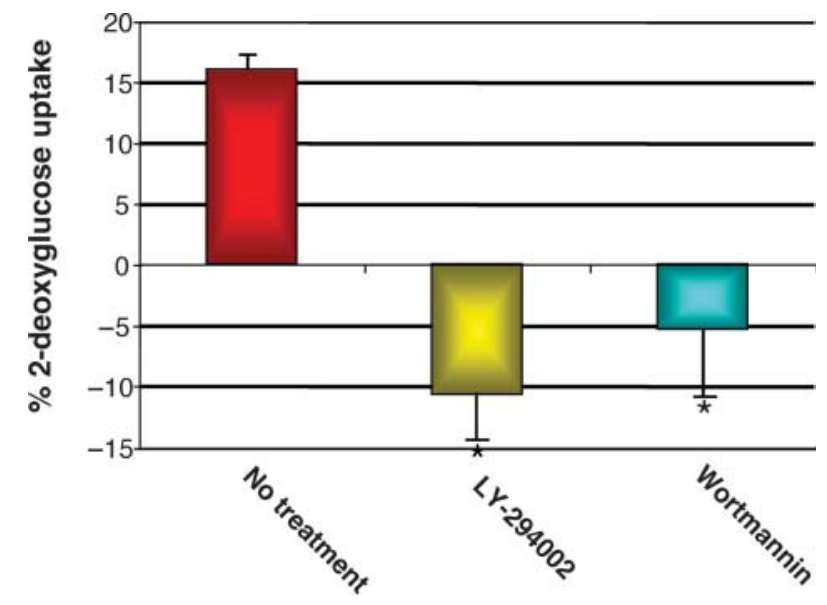

Figure 2 Insulin-stimulated glucose uptake is inhibited by LY-294002 and wortmannin. Reproduced from Riley et al. 2005b. Insulin-stimulated glucose uptake was measured in blastocysts exposed to media alone (no treatment), $250 \mu \mathrm{M} \mathrm{LY}-294002$ and $100 \mathrm{nM}$ wortmannin. The percentage of insulin-stimulated glucose uptake over basal glucose uptake is plotted.

number of implantation sites but a dramatic increase in the fetal resorption rate as compared with controls (Fig. 3B) (Riley et al. 2005a).

Inhibition of the PI3-K pathway is known to result in the induction of apoptosis in many cell systems. A recent report has shown that inhibition of $\mathrm{PI} 3-\mathrm{K}$ induces apoptosis in murine blastocysts (Gross et al. 2005). Gross et al. (2005) treated in vivo derived blastocysts with LY-294002 for $24 \mathrm{~h}$ and showed a five-fold increase in TUNEL-positive nuclei as compared with controls. Apoptotic cells were detected in both the TE as well as the ICM. Blastocysts cultured for $48 \mathrm{~h}$ completely degenerated and displayed rampant apoptosis. We have also cultured in vivo derived blastocyst for $30 \mathrm{~h}$ in vitro, in the presence of increasing concentrations of LY-294002 and demonstrated a dose-dependent increase in the number of TUNEL-positive nuclei per embryo as compared with controls (Fig. 3A) (Riley et al. 2005a). A final study conducted by Kawamura et al. (2005) demonstrated that TGF- $\alpha$ has anti-apoptotic effects on murine preimplantation embryos exposed to suboptimal culture conditions. The mechanism of the anti-apoptotic effect involves the up-regulation of survivin, a member of the inhibitor of apoptosis family. Inhibition of PI3-K using either LY-294002 or wortmannin resulted in the abrogation of TGF- $\alpha$-induced up-regulation of survivin expression in blastocysts. PI3-K activity is therefore required for the anti-apoptotic effects of TGF- $\alpha$, as mediated by survivin, in murine preimplantation embryos. Taken together the aforementioned studies demonstrate that PI3-K activity is critical for embryo development and survival during the preimplantation period and that inhibition of this pathway even for discrete periods during preimplantation development has long lasting detrimental effects on embryo development, survival and pregnancy outcome.
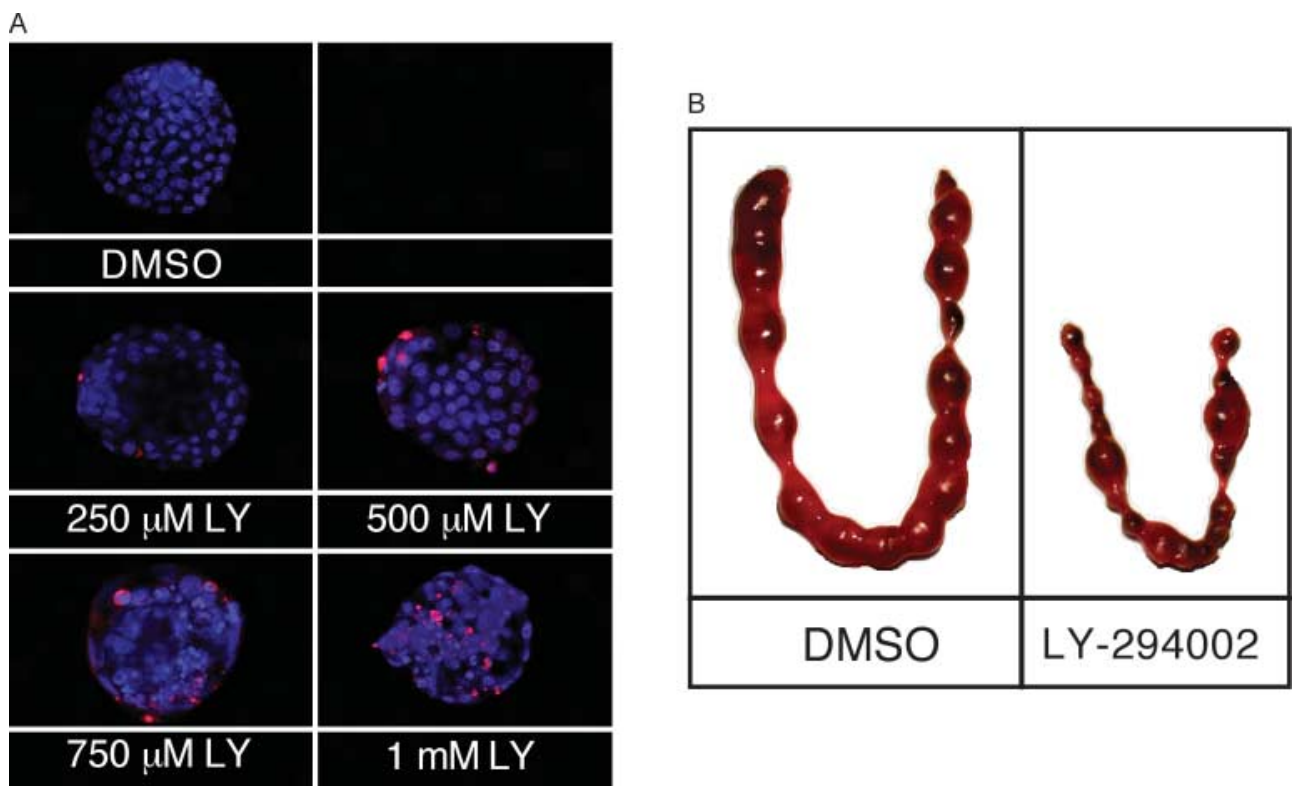

Figure 3 Inhibition of the PI3-K pathway at the blastocysts stage results in increased apoptosis and an increased frequency of fetal resorptions. Reproduced from Riley et al. 2005a. (A) Blastocysts were recovered and cultured in vitro in the presence of DMSO (vehicle control shown is for the highest concentration of LY-294002 used) or increasing concentrations of the PI3-K inhibitor LY-294002. The TUNEL assay was performed and the apoptotic nuclei are depicted in red. Embryos were counterstained with the nuclear dye TO-PRO-3 iodide as shown in blue. (B) Blastocysts were recovered and then cultured in vitro for $24 \mathrm{~h}$ in media containing either DMSO or $250 \mu \mathrm{M}$ LY-294002. Unhatched blastocysts were then transferred back into the uterine horn of pseudopregnant female recipient mice at $2.5 \mathrm{dpc}$. This panel shows representative uterine horns derived from mice into which blastocysts cultured in either DMSO or LY-294002 were transferred. 


\section{Glucose metabolism and apoptosis}

Significant progress has been made in recent years linking glucose transport, cell metabolism, the PI3-K pathway, and apoptosis both in preimplantation embryos as well as in other cell systems (for reviews see Moley \& Mueckler 2000, Moley 2001, Plas et al. 2002, Plas \& Thompson 2002). Apoptosis or programmed cell death in preimplantation embryos is a routine process by which the embryo eliminates abnormal or extraneous cells (for reviews see Hardy 1997, 1999, Jurisicova \& Acton 2004, Fabian et al. 2005). Studies demonstrated that in vivo-derived murine and porcine preimplantation embryos commonly do not show TUNEL-positive staining before the blastocyst stage (Long et al. 1998, Kamjoo et al. 2002). Jurisicova et al. (1996) demonstrated in vitro that of 200 cleavage stage human-arrested embryos, the majority showed signs of apoptosis including TUNEL-labeling of the nuclei. In addition, agents such as staurosporine do induce apoptosis very early during development (Weil et al. 1996, Matwee et al. 2000). In mammalian development, apoptosis normally occurs at the blastocyst stage and arises in both the ICM and TE (Mohr \& Trounson 1982, Handyside \& Hunter 1986, Brison \& Schultz 1997, Jurisicova et al. 1998). During this stage of development, one purpose of programmed cell death may be to eliminate cells with TE potential from the ICM (Pierce et al. 1989). There are many insults that induce apoptosis in the preimplantation embryo, one of which is glucose deprivation. Previously it was shown that the down-regulation of certain glucose transporters during preimplantation development results in increased apoptosis at the blastocyst stage. Specifically the down-regulation of either GLUT1 via high glucose concentrations in vitro or GLUT1 and GLUT8 utilizing antisense oligonucleotides results in increased apoptosis at the blastocyst stage (Chi et al. 2000a, Pinto et al. 2002a). In the case of GLUT8, down-regulation via antisense oligonucleotides leads to increased fetal resorption rates when the blastocysts were transferred into pseudopregnant recipient mice. Thus down-regulation of glucose transporter expression resulting in altered intraembryonic glucose concentrations leads to the induction of apoptosis in blastocysts.

Women with diabetes mellitus are at a higher risk for spontaneous abortions and fetal malformations (Greene et al. 1989, Casson et al. 1997, Hawthorne et al. 1997). Studies have established that an insult to the preimplantation embryo, triggered by maternal hyperglycemia, has long lasting detrimental effects on development. The hypothesis is that the decrease in glucose transport resulting from the hyperglycemia-induced down-regulation of the GLUTs, results in apoptosis of key progenitor cells or that this apoptosis and metabolic changes adversely affect the differentiation of the remaining cells. Either or both of these events then lead to either increased pregnancy resorptions or malformations. This hypothesis has been substantiated by two recent studies. First, Heilig et al.
(2003) developed a transgenic mouse over expressing GLUT1 antisense. The homozygote GLUT1AS fetuses did not survive, and demonstrated a 7 -fold higher stillborn rate than controls. Embryonic GLUT1 deficiency was associated with growth retardation $(31.1 \%$ ) and major malformations $(35.3 \%)$ consistent with those seen in infants of diabetic women including caudal regression, anencephaly, microphthalmia, and micrognathia. Examination of homozygote embryos at the blastocyst stage revealed increased apoptosis and decreased glucose transport, consistent with the embryos derived from diabetic mice, suggesting that the decrease in glucose transport and resulting apoptosis may be responsible for the developmental abnormalities seen in the GLUT1AS model. Second, in recent studies fetuses that developed from diabetic 1-cell embryos, which were transferred into normal pseudo-pregnant recipient female mice were consistently and significantly smaller than controls (K Moley, unpublished observations). Importantly, these fetuses have approximately a $10 \%$ malformation rate, whereas no malformations were detected in control fetuses. The malformations detected in the diabetic embryos consisted of skeletal anomalies and they demonstrated delayed neural tissue development. Similarly, blastocysts recovered from diabetic mice and then transferred into normal recipient females develop malformations, whereas control blastocysts do not. The control blastocysts gave rise to fetuses that had $0 \%$ malformations, were on average $1.2 \mathrm{~cm}$ in length, and had an overall resorption rate of $21 \%$. In contrast, blastocysts derived from diabetic mice gave rise to fetuses that had a $33 \%$ malformation rate, were on average $0.9 \mathrm{~cm}$ in length, and had an overall resorption rate of $52 \%$. These data establish that the preimplantation period in mammalian development is a critical stage and that a hyperglycemic insult incurred during this period alone can have long lasting detrimental effects on embryo survival and development (K Moley, unpublished observations). Other studies have also demonstrated that apoptosis induced at this early stage leads to abnormal development and poor pregnancy outcome (Chi et al. 2000a, Pinto et al. 2002b, Heilig et al. 2003).

\section{PI3-K and glucose metabolism}

One hypothesis for the etiology of diabetes-associated malformations is hyperglycemia-induced apoptosis (Pampfer et al. 1997, Phelan et al. 1997, Moley et al. 1998a). Exaggerated apoptosis during the preimplantation period may result in fetal resorption or malformation due to the loss of key progenitor cells. Using a mouse diabetes model it was shown that hyperglycemia results in decreased glucose transport at the blastocysts stage, that corresponds with decreased GLUT1 protein expression (Moley et al. 1998b). As a consequence of glucose transporter down-regulation, these blastocysts have lower intraembryonic glucose concentrations. This decrease in 
glucose utilization by the blastocyst occurs concurrently with increased apoptosis in the embryo (Chi et al. 2000a). Similar results have been found in other cell systems, including retinal pericytes (Mandarino et al. 1994, Li et al. 1998) where hyperglycemia-induced apoptosis of these cells is thought to play a role in the development of diabetic retinopathy. The cell death that occurs in the blastocysts requires both p53 and Bax (Moley et al. 1998a, Chi et al. 2000a, Keim et al. 2001). Embryos derived from diabetic Bax-deficient mice demonstrated decreased glucose uptake but no apoptosis (Chi et al. 2000a). In addition, the diabetic $\mathrm{Bax}^{-/-}$embryos exhibit a decreased resorption and malformation rate as compared with controls. This data suggests that hyperglycemia results in decreased glucose transport and that this event may trigger apoptosis in the murine blastocyst leading to poor pregnancy outcome. In vitro studies in which 2-cell embryos were cultured to the blastocysts stage in the presence of high glucose concentrations also resulted in decreased glucose transporter expression, decreased glucose uptake, and increased apoptosis (Moley et al. 1998a, Chi et al. 2000a). Therefore, inhibition of glucose uptake and thus metabolism via the down-regulation of specific glucose transporters is linked to the induction of apoptosis in murine blastocysts. These data imply that glucose transport and the maintenance of optimal intraembryonic glucose concentrations are crucial for preimplantation embryo development and survival.

Some of the first direct in vivo evidence demonstrating the importance of specific PI3-K subunits in the regulation of insulin sensitivity and glucose homeostasis came from genetic deletion studies. Mice deficient in the p85 $\alpha$ subunit of PI3-K show increased insulin sensitivity and hypoglycemia (Terauchi et al. 1999). Insulin-stimulation of muscle and adipocytes derived from the null mice results in increased GLUT4 translocation to the plasma membrane with a corresponding increase in glucose transport. In addition, heterozygous deletion of $\mathrm{p} 85 \alpha$ increases insulin sensitivity and glucose homeostasis in mice that are insulin-resistant due to heterozygous deletion of the insulin receptor or insulin receptor substrate-1 (IRS-1) (Mauvais-Jarvis et al. 2002). These data are surprising and several hypotheses have been put forward to explain this result. It has been suggested that the p85 subunit has negative regulatory effects on the p110 subunit either through competing with the p85/p110 heterodimer for receptor binding sites (Yu et al. 1998) or by inhibiting p110 activation by Ras (Chan et al. 2002, Jimenez et al. 2002). It is thought that insulin sensitivity is controlled by a equilibrium between the p85 and p110 subunits (Brachmann et al. 2005). Other studies have shown that p85 $\beta$ null mice have enhanced insulin sensitivity and are both hypoinsulinemic and hypoglycemic (Ueki et al. 2002) while the $p 50 \alpha / p 55 \alpha$ double knockout mice also display increased insulin sensitivity and insulin-stimulated glucose uptake in muscle and adipocytes (Chen et al. 2004). Finally, mice lacking $p 85 \alpha / p 50 \alpha / p 55 \alpha$ die a few days after birth and are hypoglycemic with decreased insulin levels and improved glucose tolerance (Fruman et al. 2000). Taken together these data suggest that the regulatory subunits of $\mathrm{Pl} 3-\mathrm{K}$ play an essential role in insulin signaling and glucose metabolism.

A recent study conducted in murine blastocysts has suggested that PI3-K activity is critical for glucose uptake and metabolism during the preimplantation period. Similar to what was previously found in lymphocytes deprived of exogenous growth factors (Whetton et al. 1984, Kan et al. 1994, Rathmell et al. 2000, Vander Heiden et al. 2001) inhibition of the PI3-K/Akt pathway in murine blastocysts using LY-294002, resulted in decreased cell surface expression of GLUT1 with a corresponding decrease in 2-deoxyglucose uptake (Fig. 4) (Riley et al. 2005a). Along with the decrease in glucose utilization, the blastocysts displayed increased levels of apoptosis. Thus one mechanism by which PI3-K may promote embryo survival is through the maintenance of glucose uptake by the regulation of glucose transporter expression at the cell surface. A second mechanism by which PI3-K may regulate glycolysis is through its effects on the activity of glycolytic enzymes. Inhibition of the PI3-K pathway using LY-294002 resulted in decreased hexokinase activity at the blastocyst stage. Hexokinase is the first enzyme involved in the glycolytic pathway. It converts intracellular glucose to glucose-6-phosphate and thus a decrease in hexokinase activity may have a large effect on the overall rate of glucose utilization. It was previously shown in lymphocytes that the ability of activated Akt to inhibit apoptosis requires the presence of glucose and is linked to its metabolism (Plas et al. 2001, Rathmell et al. 2003). A separate study demonstrated the anti-apoptotic activity of Akt requires the first committed step of glucose metabolism that is catalyzed by hexokinase (Gottlob et al. 2001). Finally, Akt was shown to increase hexokinase activity (Gottlob et al. 2001, Rathmell et al. 2003). Taken together these data suggest that the PI3-K/Akt pathway is critical for glucose metabolism in the preimplantation embryo via its ability to regulate GLUT1 expression at the plasma membrane and thus glucose uptake by blastocysts as well as the activity of a key glycolytic enzyme.

The inhibition of glucose metabolism is in large part sufficient to explain the physiologic outcomes of inhibiting the PI3-K pathway in preimplantation embryos. We have demonstrated that iodoacetate, a glyceraldehyde 3-phosphate dehydrogenase (GAPDH) inhibitor, induces apoptosis in both blastocysts and TS cells (Fig. 5A) (Riley et al. 2005a). GAPDH is a glycolytic enzyme which catalyzes the conversion of glyceraldehyde 3-phosphate to 1,3 bisphosphoglycerate resulting in the production of $\mathrm{NADH}$. These findings suggest that the maintenance of glycolysis is important for embryo survival as the inhibition of this pathway results in the induction of cell death. Importantly, a significant increase in the number of fetal resorptions was seen in embryos derived from iodoacetate-treated blastocysts as compared with controls 


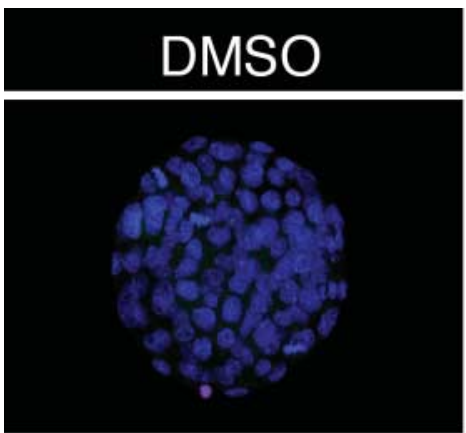

\section{Rabbit lgG}

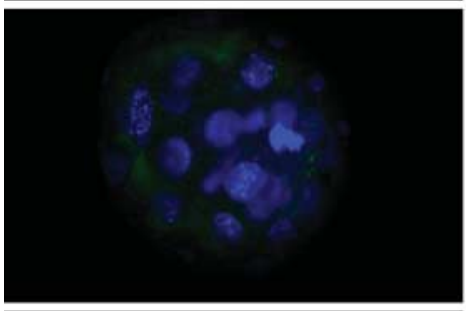

Normal Sera

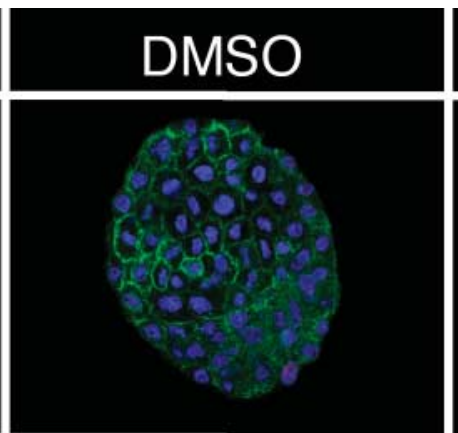

GLUT-1

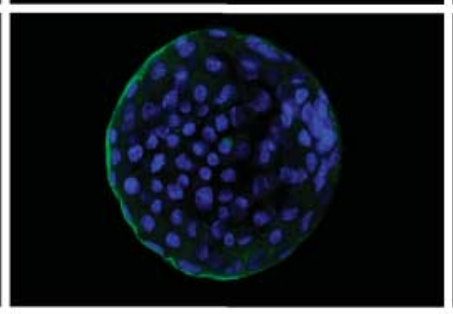

GLUT-3

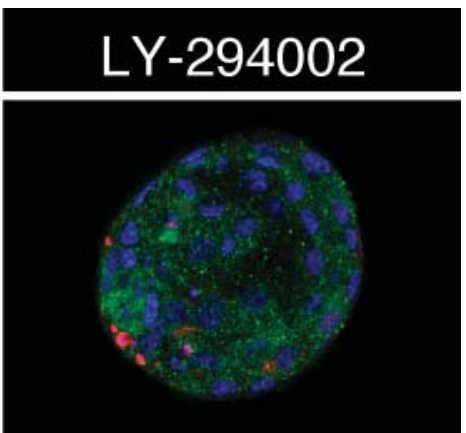

GLUT-1

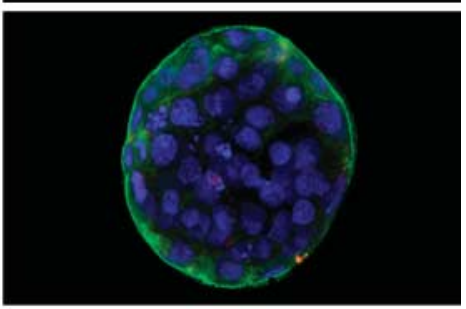

GLUT-3

Figure 4 Inhibition of PI3-K results in decreased GLUT1 expression at the plasma membrane. Reproduced from Riley et al. 2005a. Blastocysts were recovered and cultured in vitro in the presence of DMSO (vehicle control) or $250 \mu \mathrm{M} \mathrm{LY}-294002$. The embryos were subjected to the TUNEL assay (red), immunofluorescent staining for GLUT1 or GLUT3 (green), and nuclear staining (blue).
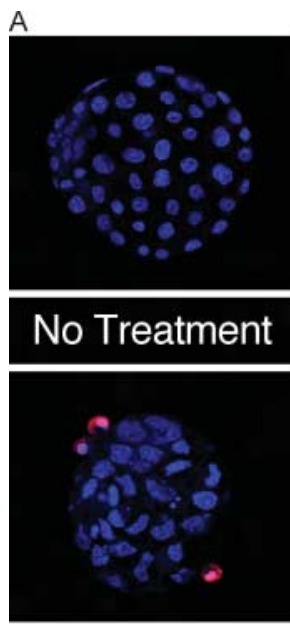

$5 \mu \mathrm{M}$ IA
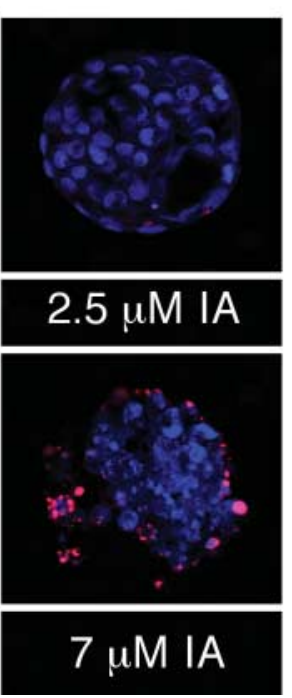

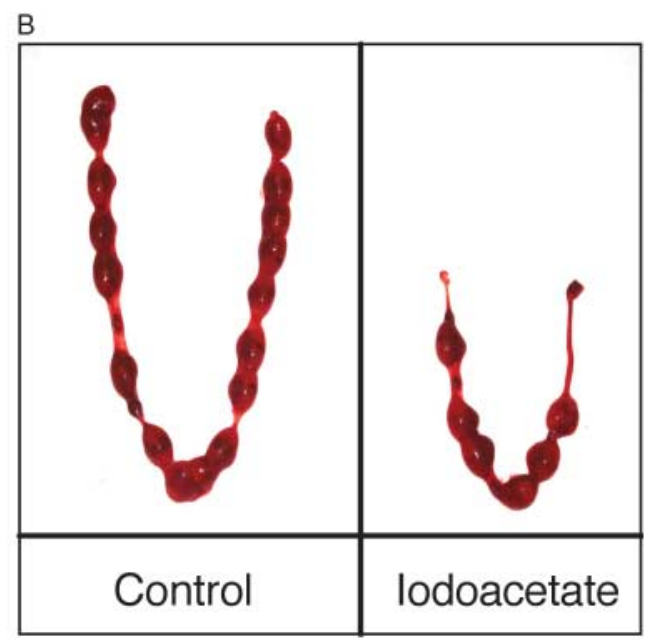

Figure 5 Inhibition of GAPDH results in the induction of apoptosis in blastocysts and an increased frequency of fetal resorptions. Reproduced from Riley et al. 2005a. (A) Blastocysts were recovered and cultured in vitro in the presence of HTF media alone or increasing concentrations of the GAPDH inhibitor iodoacetate. The TUNEL assay was performed and the apoptotic nuclei are depicted in red. Embryos were counterstained with the nuclear dye TO-PRO-3 iodide as shown in blue. (B) Blastocysts were recovered and then cultured in vitro for $24 \mathrm{~h}$ in media containing either HTF alone or $2.5 \mu \mathrm{M}$ iodoacetate. Unhatched blastocysts were then transferred back into the uterine horn of pseudopregnant female recipient mice at $2.5 \mathrm{dpc}$. This panel shows representative uterine horns derived from mice into which blastocysts cultured in either control media or iodoacetate were transferred.

(Fig. 5B) (Riley et al. 2005a). Therefore, the maintenance of glycolysis at the blastocyst stage is crucial for subsequent developmental success. Importantly, one mechanism by which $\mathrm{PI} 3-\mathrm{K}$ promotes cell survival and reproductive success in preimplantation embryos is through the maintenance of glucose metabolism. A previous study showed that the inhibition of glycolysis later in development also has deleterious effects on the fetus. 
Wentzel et al. (2003) demonstrated that the inhibition of GAPDH activity by iodoacetate in gestational day 11 rat embryos, results in increased malformation rates as well as decreased size, somite number, and DNA and protein content. Thus the inhibition of glycolysis has harmful effects on both pre- and post-implantation embryo development.

\section{Conclusion}

A growing body of evidence suggests that the PI3-K pathway plays a critical role in embryo survival. In addition $\mathrm{PI} 3-\mathrm{K}$ activity regulates glucose utilization in the preimplantation blastocyst. The ability of PI3-K to promote embryo survival and metabolism depends on its ability to maintain glucose uptake and the activity of at least one glycolytic enzyme (Fig. 6). It will be important to determine whether this key survival pathway is inhibited during the preimplantation period in maternal disease states such as diabetes and insulin resistance that are known to affect glucose utilization in the preimplantation embryo and have adverse effects on pregnancy outcome.

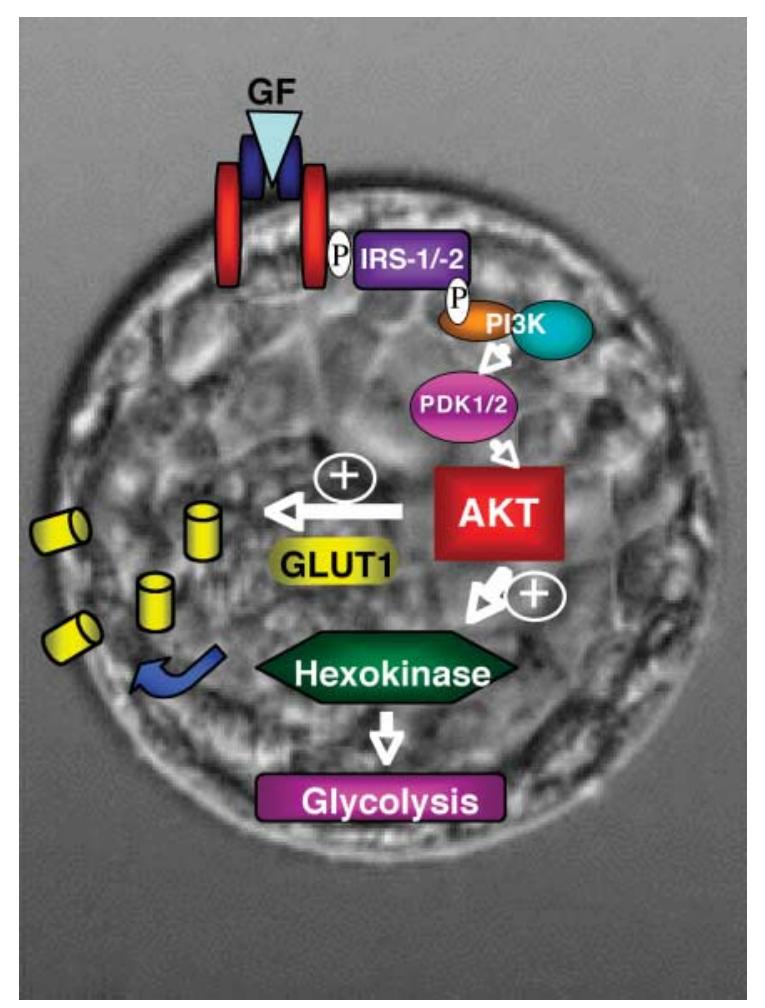

Figure 6 PI3-K activity regulates glucose utilization in the preimplantation blastocyst. The ability of PI3-K to promote embryo survival and metabolism depends in part on its ability to maintain glucose uptake. $\mathrm{PI} 3-\mathrm{K}$ activity is required to retain the facilitative glucose transporter GLUT1 at the plasma membrane. It is thought that Akt is involved in the mechanism by which PI3-K promotes GLUT1 cell surface expression. In addition the PI3-K pathway is required for the optimal activity of at least one glycolytic enzyme in blastocysts.

\section{Acknowledgements}

This work is supported by a Juvenile Diabetes Research Foundation Fellowship to J K R and by HD40390 and DK0070351 from the National Institutes of Health to $\mathrm{K} \mathrm{H} \mathrm{M}$. The authors declare that there is no conflict of interest that would prejudice the impartiality of this scientific work.

\section{References}

Adjaye J, Huntriss J, Herwig R, Benkahla A, Brink T, Wierling C, Hultschig C, Groth D, Yaspo ML, Picton H, Gosden R \& Lehrach H 2005 Primary differentiation in the human blastocyst: Comparative molecular portraits of ICM and TE cells. Stem Cells 23 1514-1525.

Aghayan M, Rao LV, Smith RM, Jarett L, Charron MJ, Thorens B \& Heyner S 1992 Developmental expression and cellular localization of glucose transporter molecules during mouse preimplantation development. Development 115 305-312.

Augustin R, Pocar P, Navarrete Santos A, Wrenzycki C, Gandolfi F, Niemann H \& Fischer B 2001 Glucose transporter expression is developmentally regulated in in vitro derived bovine preimplantation embryos. Molecular Reproduction and Development $\mathbf{6 0}$ $370-376$.

Augustin R, Pocar P, Wrenzycki C, Niemann H \& Fischer B 2003 Mitogenic and anti-apoptotic activity of insulin on bovine embryos produced in vitro. Reproduction 126 91-99.

Bi L, Okabe I, Bernard DJ, Wynshaw-Boris A \& Nussbaum RL 1999 Proliferative defect and embryonic lethality in mice homozygous for a deletion in the p110alpha subunit of phosphoinositide 3-kinase. Journal of Biological Chemistry 274 10963-10968.

Bi L, Okabe I, Bernard DJ \& Nussbaum RL 2002 Early embryonic lethality in mice deficient in the p110beta catalytic subunit of PI 3-kinase. Mammalian Genome 13 169-172.

Brachmann SM, Ueki K, Engelman JA, Kahn RC \& Cantley LC 2005 Phosphoinositide 3-kinase catalytic subunit deletion and regulatory subunit deletion have opposite effects on insulin sensitivity in mice. Molecular and Cellular Biology 25 1596-1607.

Brazil DP \& Hemmings BA 2001 Ten years of protein kinase B signalling: a hard Akt to follow. Trends in Biochemical Sciences $\mathbf{2 6}$ 657-664.

Brison DR \& Schultz RM 1997 Apoptosis during mouse blastocyst formation: evidence for a role for survival factors including transforming growth factor alpha. Biology of Reproduction $\mathbf{5 6}$ 1088-1096.

Byrne AT, Southgate J, Brison DR \& Leese HJ 2002 Regulation of apoptosis in the bovine blastocyst by insulin and the insulin-like growth factor (IGF) superfamily. Molecular Reproduction and Development 62 489-495.

Cantley LC 2002 The phosphoinositide 3-kinase pathway. Science $2961655-1657$.

Carayannopoulos M, Chi M, Cui Y, Pingsterhaus J \& Moley K 2000 GLUT8, a glucose transporter responsible for insulin-stimulated uptake in the blastocyst. PNAS 97 7313-7318.

Carayannopoulos MO, Schlein A, Wyman A, Chi M, Keembiyehetty C \& Moley KH 2004 GLUT9 is differentially expressed and targeted in the preimplantation embryo. Endocrinology 145 1435-1443.

Casslen B \& Nilsson B 1984 Human uterine fluid, examined in undiluted samples for osmolarity and the concentrations of inorganic ions, albumin, glucose, and urea. American Journal of Obstetics and Gynecology 150 877-881.

Casson IF, Clarke CA, Howard CV, McKendrick O, Pennycook S, Pharoah POD, Platt MJ, Stanisstreet $M$, van Velszen D \& Walkinshaw S 1997 Outcomes of pregnancy in insulin dependent diabetic women: results of a five year population cohort study. British Medical Journal 315 275-278. 
Chan TO, Rittenhouse SE \& Tsichlis PN 1999 AKT/PKB and other D3 phosphoinositide-regulated kinases: kinase activation by phosphoinositide-dependent phosphorylation. Annual Review of Biochemistry 68 965-1014.

Chan TO, Rodeck U, Chan AM, Kimmelman AC, Rittenhouse SE, Panayotou G \& Tsichlis PN 2002 Small GTPases and tyrosine kinases coregulate a molecular switch in the phosphoinositide 3-kinase regulatory subunit. Cancer Cell 1 181-191.

Chen D, Mauvais-Jarvis F, Bluher M, Fisher SJ, Jozsi A, Goodyear LJ, Ueki K \& Kahn CR 2004 p50alpha/p55alpha phosphoinositide 3-kinase knockout mice exhibit enhanced insulin sensitivity. Molecular and Cellular Biology 24 320-329.

Chi MM, Pingsterhaus J, Carayannopoulos M \& Moley KH 2000a Decreased glucose transporter expression triggers BAX-dependent apoptosis in the murine blastocyst. Journal of Biological Chemistry $27540252-40257$.

Chi MM, Schlein AL \& Moley KH 2000b High insulin-like growth factor 1 (IGF-1) and insulin concentrations trigger apoptosis in the mouse blastocyst via down-regulation of the IGF-1 receptor. Endocrinology $1414784-4792$.

Cope DL, Holman GD, Baldwin SA \& Wolstenholme AJ 1994 Domain assembly of the GLUT1 glucose transporter. Biochemical Journal 300 (Pt 2) 291-294.

Dan-Goor M, Sasson S, Davarashvili A \& Almagor M 1997 Expression of glucose transporter and glucose uptake in human oocytes and preimplantation embryos. Human Reproduction 12 2508-2510.

Darakhshan F, Hajduch E, Kristiansen S, Richter EA \& Hundal HS 1998 Biochemical and functional characterization of the GLUT5 fructose transporter in rat skeletal muscle. Biochemical Journal 336 (Pt 2) 361-366.

Dudek H, Datta SR, Franke TF, Birnbaum MJ, Yao R, Cooper GM, Segal RA, Kaplan DR \& Greenberg ME 1997 Regulation of neuronal survival by the serine-threonine protein kinase Akt. Science $275661-665$.

Fabian D, II'kova G, Rehak P, Czikkova S, Baran V \& Koppel J 2004 Inhibitory effect of IGF-I on induced apoptosis in mouse preimplantation embryos cultured in vitro. Theriogenology $\mathbf{6 1}$ 745-755.

Fabian D, Koppel J \& Maddox-Hyttel P 2005 Apoptotic processes during mammalian preimplantation development. Theriogenology $64221-231$.

Fruman DA, Mauvais-Jarvis F, Pollard DA, Yballe CM, Brazil D, Bronson RT, Kahn CR \& Cantley LC 2000 Hypoglycaemia, liver necrosis and perinatal death in mice lacking all isoforms of phosphoinositide 3-kinase p85 alpha. Nature Genetics 26 379-382.

Gardner DK \& Leese HJ 1988 The role of glucose and pyruvate transport in regulating nutrient utilization by preimplantation mouse embryos. Development 104 423-429.

Gardner HG \& Kaye PL 1991 Insulin increases cell numbers and morphological development in mouse pre-implantation embryos in vitro. Reproduction, Fertility and Development 3 79-91.

Gottlob K, Majewski N, Kennedy S, Kandel E, Robey RB \& Hay N 2001 Inhibition of early apoptotic events by Akt/PKB is dependent on the first committed step of glycolysis and mitochondrial hexokinase. Genes Development 15 1406-1418.

Greene MF, Hare JW, Cloherty JP, Benacerraf BR \& Soeldner JS 1989 First-trimester hemoglobin A1 and risk for major malformation and spontaneous abortion in diabetic pregnancy. Teratology $39225-231$.

Gross VS, Hess M \& Cooper GM 2005 Mouse embryonic stem cells and preimplantation embryos require signaling through the phosphatidylinositol 3-kinase pathway to suppress apoptosis. Molecular Reproduction and Development 70 324-332.

Hajduch E, Darakhshan F \& Hundal HS 1998 Fructose uptake in rat adipocytes: GLUT5 expression and the effects of streptozotocininduced diabetes. Diabetologia 41 821-828.

Hamatani T, Daikoku T, Wang H, Matsumoto H, Carter MG, Ko MS \& Dey SK 2004 Global gene expression analysis identifies molecular pathways distinguishing blastocyst dormancy and activation. PNAS 101 10326-10331.

Handyside A \& Hunter S 1986 Cell division and death in the mouse blastocyst before implantation. Roux's Archives of Developmental Biology 195 519-525.

Hardy K 1997 Cell death in the mammalian blastocyst. Molecular Human Reproduction 3 919-925.

Hardy K 1999 Apoptosis in the human embryo. Reviews in Reproduction 4 125-134.

Hardy K \& Spanos S 2002 Growth factor expression and function in the human and mouse preimplantation embryo. Journal of Endocrinology $172221-236$.

Harvey MB \& Kaye PL 1990 Insulin increases the cell number of the ICM and stimulates morphological development of mouse blastocysts in vitro. Development 110 963-967.

Harvey MB \& Kaye PL 1991 Mouse blastocysts respond metabolically to short-term stimulation by insulin and IGF-1 through the insulin receptor. Molecular Reproduction and Development 29 $253-258$.

Hawthorne G, Robson S, Ryall EA, Sen D, Roberts SH \& Ward Platt MP 1997 Prospective population based survey of outcome of pregnancy in diabetic women: results of the Northern Diabetic Pregnancy Audit, 1994 [see comments]. British Medical Journal 315 279-281.

Heilig CW, Saunders T, Brosius FC 3rd, Moley K, Heilig K, Baggs R, Guo L \& Conner D 2003 Glucose transporter-1-deficient mice exhibit impaired development and deformities that are similar to diabetic embryopathy. PNAS 100 15613-15618.

Herrler A, Krusche CA \& Beier HM 1998 Insulin and insulin-like growth factor-I promote rabbit blastocyst development and prevent apoptosis. Biology of Reproduction 59 1302-1310.

Hogan A, Heyner S, Charron MJ, Copeland NG, Gilbert DJ, Jenkins MA, Thorens B \& Schultz GA 1991 Glucose transporter gene expression in early mouse embryos. Development 113 363-372.

Jimenez C, Hernandez C, Pimentel B \& Carrera AC 2002 The p85 regulatory subunit controls sequential activation of phosphoinositide 3-kinase by Tyr kinases and Ras. Journal of Biological Chemistry 277 41556-41562.

Joost HG \& Thorens B 2001 The extended GLUT-family of sugar/ polyol transport facilitators: nomenclature, sequence characteristics, and potential function of its novel members. Molecular Membrane Biology 18 247-256.

Joost HG, Bell GI, Best JD, Birnbaum MJ, Charron MJ, Chen YT, Doege H, James DE, Lodish HF, Moley KH, Moley JF, Mueckler M, Rogers S, Schurmann A, Seino S \& Thorens B 2002 Nomenclature of the GLUT/SLC2A family of sugar/polyol transport facilitators. American Journal of Physiology, Endocrinology and Metabolism 282 E974-E976.

Jurisicova A \& Acton BM 2004 Deadly decisions: the role of genes regulating programmed cell death in human preimplantation embryo development. Reproduction 128 281-291.

Jurisicova A, Varmuza S \& Casper RF 1996 Programmed cell death and human embryo fragmentation. Molecular Human Reproduciton 2 93-98.

Jurisicova A, Rogers I, Fasciani A, Casper RF \& Varmuza S 1998 Effect of maternal age and conditions of fertilization on programmed cell death during murine preimplantation embryo development. Molecular Human Reproduction 4 139-145.

Kamjoo M, Brison DR \& Kimber SJ 2002 Apoptosis in the preimplantation mouse embryo: effect of strain difference and in vitro culture. Molecular Reproduction and Development 61 67-77.

Kan O, Baldwin SA \& Whetton AD 1994 Apoptosis is regulated by the rate of glucose transport in an IL-3-dependent haemopoietic cell line. Biochemical Society Transactions 22 275S.

Kawamura K, Fukuda J, Shimizu Y, Kodama H \& Tanaka T 2005 Survivin Contributes to the Anti-Apoptotic Activities of Transforming Growth Factor alpha in Mouse Blastocysts Through Phosphatidylinositol 3'-Kinase Pathway. Biology of Reproduction 73 1094-1101. 
Keim AL, Chi MM \& Moley KH 2001 Hyperglycemia-induced apoptotic cell death in the mouse blastocyst is dependent on expression of p53. Molecular Reproduction and Development 60 214-224.

Khwaja A, Rodriguez-Viciana P, Wennstrom S, Warne PH \& Downward J 1997 Matrix adhesion and Ras transformation both activate a phosphoinositide $3-\mathrm{OH}$ kinase and protein kinase B/Akt cellular survival pathway. EMBO Journal 16 2783-2793.

Korgun ET, Demir R, Hammer A, Dohr G, Desoye G, Skofitsch G \& Hahn T 2001 Glucose transporter expression in rat embryo and uterus during decidualization, implantation, and early postimplantation. Biology of Reproduction 65 1364-1370.

Kristiansen S, Darakhshan F, Richter EA \& Hundal HS 1997 Fructose transport and GLUT-5 protein in human sarcolemmal vesicles. American Journal of Physiology 273 E543-E548.

Leese HJ \& Barton AM 1984 Pyruvate and glucose uptake by mouse ova and preimplantation embryos. Journal of Reproduction and Fertility 72 9-13.

Lelievre E, Bourbon PM, Duan LJ, Nussbaum RL \& Fong GH 2005 Deficiency in the p110alpha subunit of PI3K results in diminished Tie2 expression and Tie2(-/-)-like vascular defects in mice. Blood 105 3935-3938.

Lequarre AS, Grisart B, Moreau B, Schuurbiers N, Massip A \& Dessy F 1997 Glucose metabolism during bovine preimplantation development: analysis of gene expression in single oocytes and embryos. Molecular Reproduction and Development 48 216-226.

Li W, Liu X, He Z, Yanoff M, Jian B \& Ye X 1998 Expression of apoptosis regulatory genes by retinal pericytes after rapid glucose reduction. Investagative Opthalmology and Visual Science 39 $1535-1543$.

Long CR, Dobrinsky JR, Garrett WM \& Johnson LA 1998 Dual labeling of the cytoskeleton and DNA strand breaks in porcine embryos produced in vivo and in vitro. Molecular Reproduction and Development 51 59-65.

Lu DP, Chandrakanthan V, Cahana A, Ishii S \& O'Neill C 2004 Trophic signals acting via phosphatidylinositol-3 kinase are required for normal pre-implantation mouse embryo development. Journal of Cell Science 117 1567-1576.

Makarevich AV \& Markkula M 2002 Apoptosis and cell proliferation potential of bovine embryos stimulated with insulin-like growth factor I during in vitro maturation and culture. Biology of Reproduction 66 386-392.

Mandarino LJ, Finlayson J \& Hassell JR 1994 High glucose downregulates glucose transport activity in retinal capillary pericytes but not endothelial cells. Investigations in Ophthalmology and Visual Science 35 964-972.

Matsui M, Takahashi Y, Hishinuma M \& Kanagawa H 1995 Insulin and insulin-like growth factor-I (IGF-I) stimulate the development of bovine embryos fertilized in vitro. Journal of Veterinary Medical Science 57 1109-1111.

Matwee C, Betts DH \& King WA 2000 Apoptosis in the early bovine embryo. Zygote 8 57-68.

Mauvais-Jarvis F, Ueki K, Fruman DA, Hirshman MF, Sakamoto K, Goodyear LJ, lannacone M, Accili D, Cantley LC \& Kahn CR 2002 Reduced expression of the murine p85alpha subunit of phosphoinositide 3-kinase improves insulin signaling and ameliorates diabetes. Journal of Clinical Investigations 109 141-149.

Mohr LR \& Trounson AO 1982 Comparative ultrastructure of hatched human, mouse and bovine blastocysts. Journal of Reproduction and Fertility 66 499-504.

Moley KH 2001 Hyperglycemia and apoptosis: mechanisms for congenital malformations and pregnancy loss in diabetic women. Trends in Endocrinological Metabolism 12 78-82.

Moley KH \& Mueckler MM 2000 Glucose transport and apoptosis. Apoptosis $\mathbf{5}$ 99-105.

Moley KH, Chi M \& Mueckler M 1998a Maternal hyperglycemia alters glucose transport and utilization in mouse preimplantation embryos. American Journal of Physiology 275 E38-E47.

Moley KH, Chi MM, Knudson CM, Korsmeyer SJ \& Mueckler MM 1998b Hyperglycemia induces apoptosis in preimplantation embryos via cell death effector pathways. Nature Medicine 12 $1421-1424$.

Morita Y, Tsutsumi O, Hosoya I, Taketani Y, Oka Y \& Kato T 1992 Expression and possible function of glucose transporter protein GLUT1 during preimplantation mouse development from oocytes to blastocysts. Biochemical and Biophysical Research Communications 188 8-15.

Mueckler M, Caruso C, Baldwin SA, Panico M, Blench I, Morris HR, Allard WJ, Lienhard GE \& Lodish HF 1985 Sequence and structure of a human glucose transporter. Science 229 941-945.

Navarrete Santos A, Augustin R, Lazzari G, Galli C, Sreenan JM \& Fischer B 2000 The insulin-dependent glucose transporter isoform 4 is expressed in bovine blastocysts. Biochemical and Biophysical Research Communications 271 753-760.

Navarrete Santos A, Tonack S, Kirstein M, Kietz S \& Fischer B 2004a Two insulin-responsive glucose transporter isoforms and the insulin receptor are developmentally expressed in rabbit preimplantation embryos. Reproduction 128 503-516.

Navarrete Santos A, Tonack S, Kirstein M, Pantaleon M, Kaye P \& Fischer B 2004b Insulin acts via mitogen-activated protein kinase phosphorylation in rabbit blastocysts. Reproduction 128 517-526.

Pampfer S, Vanderheyden I, McCracken JE, Vesela J \& De Hertogh R 1997 Increased cell death in rat blastocysts exposed to maternal diabetes in utero and to high glucose or tumor necrosis factoralpha in vitro. Development 124 4827-4836.

Pantaleon M, Harvey MB, Pascoe WS, James DE \& Kaye PL 1997 Glucose transporter GLUT3: Ontogeny, targeting and role in the mouse blastocyst. PNAS 94 3795-3800.

Pantaleon M, Ryan JP, Gil M \& Kaye PL 2001 An unusual subcellular localization of GLUT1 and link with metabolism in oocytes and preimplantation mouse embryos. Biology of Reproduction 64 1247-1254.

Pantaleon M \& Kaye PL 1996 IGF-I and insulin regulate glucose transport in mouse blastocysts via IGF-I receptor. Molecular Reproduction and Development 44 71-76.

Phelan SA, Ito M \& Loeken MR 1997 Neural tube defects in embryos of diabetic mice: role of the Pax-3 gene and apoptosis. Diabetes $461189-1197$.

Philpott KL, McCarthy MJ, Klippel A \& Rubin LL 1997 Activated phosphatidylinositol 3-kinase and Akt kinase promote survival of superior cervical neurons. Journal of Cell Biology 139 809-815.

Pierce GB, Lewellyn AL \& Parchment RE 1989 Mechanism of programmed cell death in the blastocyst. PNAS 86 3654-3658.

Pinto A, Carayannopoulos M, Hoehn A, Dowd L \& Moley K 2002a GLUT8 expression and translocation are critical for murine blastocyst survival. Biology of Reproduction 66 1729-1733.

Pinto AB, Schlein AL \& Moley KH 2002b Preimplantation exposure to high insulin-like growth factor I concentrations results in increased resorption rates in vivo. Human Reproduction 17 $457-462$.

Plas DR, Talapatra S, Edinger AL, Rathmell JC \& Thompson CB 2001 $\mathrm{Akt}$ and $\mathrm{BCl}-\mathrm{xL}$ promote growth factor-independent survival through distinct effects on mitochondrial physiology. Journal of Biological Chemistry 276 12041-12048.

Plas DR, Rathmell JC \& Thompson CB 2002 Homeostatic control of lymphocyte survival: potential origins and implications. Nature Immunology 3 515-521.

Plas DR \& Thompson CB 2002 Cell metabolism in the regulation of programmed cell death. Trends in Endocrinology and Metabolism $1375-78$.

Rathmell JC, Vander Heiden MG, Harris MH, Frauwirth KA \& Thompson CB 2000 In the absence of extrinsic signals, nutrient utilization by lymphocytes is insufficient to maintain either cell size or viability. Molecular Cell 6 683-692.

Rathmell JC, Fox CJ, Plas DR, Hammerman PS, Cinalli RM \& Thompson CB 2003 Akt-directed glucose metabolism can prevent Bax conformation change and promote growth factor-independent survival. Molecular and Cellular Biology 23 7315-7328. 
Riley JK, Carayannopoulos MO, Wyman AH, Chi M \& Moley KH 2005a PI3-kinase activity is critical for glucose metabolism and embryo survival in murine blastocysts. Journal of Biological Chemistry (In Press).

Riley JK, Carayannopoulos MO, Wyman AH, Chi M, Ratajczak CK \& Moley KH 2005b The PI3K/Akt pathway is present and functional in the preimplantation mouse embryo. Developmental Biology $284377-386$.

Robinson DH, Smith PR \& Benos DJ 1990 Hexose transport in preimplantation rabbit blastocysts. Journal of Reproduction and Fertility 89 1-11.

Rogers S, Macheda ML, Docherty SE, Carty MD, Henderson MA, Soeller WC, Gibbs EM, James DE \& Best JD 2002 Identification of a novel glucose transporter-like protein-GLUT-12. American Journal of Physiology, Endocrinology and Metabolism 282 E733-E738.

Schultz GA, Hogan A, Watson AJ, Smith RM \& Heyner S 1992 Insulin, insulin-like growth factors and glucose transporters: temporal patterns of gene expression in early murine and bovine embryos. Reproduction, Fertility and Development 4 361-371.

Shepherd PR, Gibbs EM, Wesslau C, Gould GW \& Kahn BB 1992 Human small intestine facilitative fructose/glucose transporter (GLUT5) is also present in insulin-responsive tissues and brain. Investigation of biochemical characteristics and translocation. Diabetes 41 1360-1365.

Sirisathien S \& Brackett BG 2003 TUNEL analyses of bovine blastocysts after culture with EGF and IGF-I. Molecular Reproduction and Development 65 51-56.

Sirisathien S, Hernandez-Fonseca HJ \& Brackett BG 2003 Influences of epidermal growth factor and insulin-like growth factor-I on bovine blastocyst development in vitro. Animal Reproduction Science 77 21-32.

Smith RM, Garside WT, Aghayan M, Shi CZ, Shah N, Jarett L \& Heyner S 1993 Mouse preimplantation embryos exhibit receptormediated binding and transcytosis of maternal insulin-like growth factor I. Biology of Reproduction 49 1-12.

Songyang Z, Baltimore D, Cantley LC, Kaplan DR \& Franke TF 1997 Interleukin 3-dependent survival by the Akt protein kinase. PNAS 94 11345-11350.

Spanos S, Becker DL, Winston RM \& Hardy K 2000 Anti-apoptotic action of insulin-like growth factor-I during human preimplantation embryo development. Biology of Reproduction $\mathbf{6 3}$ $1413-1420$

Terauchi Y, Tsuji Y, Satoh S, Minoura H, Murakami K, Okuno A, Inukai K, Asano T, Kaburagi Y, Ueki K, Nakajima H, Hanafusa T, Matsuzawa $Y$, Sekihara $H$, Yin $Y$, Barrett JC, Oda $H$, Ishikawa $T$, Akanuma Y \& Komuro I 1999 Increased insulin sensitivity and hypoglycaemia in mice lacking the p85 alpha subunit of phosphoinositide 3-kinase. Nature Genetics 21 230-235.

Thompson JE \& Thompson CB 2004 Putting the rap on Akt. Journal of Clinical Oncology 22 4217-4226.
Tonack S, Fischer B \& Navarrete Santos A 2004 Expression of the insulin-responsive glucose transporter isoform 4 in blastocysts of C57/BL6 mice. Anatomy and Embryology 208 225-230.

Ueki K, Yballe CM, Brachmann SM, Vicent D, Watt JM, Kahn CR \& Cantley LC 2002 Increased insulin sensitivity in mice lacking p85beta subunit of phosphoinositide 3-kinase. PNAS 99 419-424.

Vander Heiden MG, Plas DR, Rathmell JC, Fox CJ, Harris MH \& Thompson CB 2001 Growth factors can influence cell growth and survival through effects on glucose metabolism. Molecular and Cellular Biology 21 5899-5912.

Wales RG 1986 Measurement of metabolic turnover in single mouse embryos. Journal of Reproduction and Fertility 76 717-725

Weil M, Jacobson MD, Coles HS, Davies TJ, Gardner RL, Raff KD \& Raff MC 1996 Constitutive expression of the machinery for programmed cell death. Journal of Cell Biology 133 1053-1059.

Welsh GI, Hers I, Berwick DC, Dell G, Wherlock M, Birkin R, Leney S \& Tavare JM 2005 Role of protein kinase B in insulin-regulated glucose uptake. Biochemical Society Transactions 33 346-349.

Wentzel P, Ejdesjo A \& Eriksson UJ 2003 Maternal diabetes in vivo and high glucose in vitro diminish GAPDH activity in rat embryos. Diabetes 52 1222-1228.

Whetton AD, Bazill GW \& Dexter TM 1984 Haemopoietic cell growth factor mediates cell survival via its action on glucose transport. EMBO Journal 3 409-413.

Wood IS \& Trayhurn P 2003 Glucose transporters (GLUT and SGLT): expanded families of sugar transport proteins. British Journal of Nutrition 89 3-9.

Woodgett JR 2005 Recent advances in the protein kinase B signaling pathway. Current Opinion in Cell Biology 17 150-157.

Wrenzycki C, Herrmann D, Carnwath JW \& Niemann H 1998 Expression of RNA from developmentally important genes in preimplantation bovine embryos produced in TCM supplemented with BSA. Journal of Reproduciton and Fertility 112 387-398.

Yu J, Zhang Y, Mcllroy J, Rordorf-Nikolic T, Orr GA \& Backer JM 1998 Regulation of the p85/p110 phosphatidylinositol 3'-kinase: stabilization and inhibition of the p110alpha catalytic subunit by the p85 regulatory subunit. Molecular and Cellular Biology 18 $1379-1387$.

Zhou Y, Kaye PL \& Pantaleon M 2004 Identification of the facilitative glucose transporter 12 gene Glut12 in mouse preimplantation embryos. Gene Expression Patterns 4 621-631.

Received 3 November 2005

First decision 17 November 2005

Revised manuscript received 9 January 2006

Accepted 19 January 2006 